\title{
COURSE OF LARYNGEAL FUNCTION RECOVERY AFTER RECONSTRUCTION OF THE LARYNGEAL NERVES \\ Contributions:
} A Study design/planning B Data collection/entry C Data analysis/statistic D Data interpretation E Preparation of manuscript F Literature analysis/search $G$ Funds collection

\section{Paulina Krasnodebska ${ }^{A-F}$, Agata Szkielkowska ${ }^{A, C, D, G}$}

Audiology and Phoniatrics Clinic, Institute of Physiology and Pathology of Hearing, Poland

Corresponding author: Paulina Krasnodebska, Institute of Physiology and Pathology of Hearing, World Hearing Center, 05-830 Kajetany, 17 Mokra St., Poland;

email: p.krasnodebska@ifps.org.pl, tel. +48 223650351

\begin{abstract}
Background: According to the literature, the rate of laryngeal paralysis after thyroid surgery is as high as several percent. For oncological operations the rate can reach $20 \%$. The return of laryngeal function depends on the degree of nerve damage. Surgical procedures are required to increase the likelihood of nerve function recovery. Three methods of phonosurgery are currently used. The first is based on injecting auto or alloplastic materials into the vocal fold. The second interferes with the skeleton of the laryngeal cartilages; according to the Isshiki classification, it includes type I thyreoplasty (medialisation thyreoplasty), optionally with complementary arytenoid adduction. The third method reconstructs the laryngeal nerves. Combinations of the three methods are increasingly used. Conservative treatment including phoniatric voice rehabilitation should be started as early as possible.
\end{abstract}

Case report: The paper presents a case report of a patient after thyroid surgery due to papillary carcinoma, complicated by bilateral laryngeal paralysis and aphonia.

Conclusions: Functional Voice Therapy started just after healing of the postoperative wound in the neck eliminated abnormal compensatory mechanisms of phonation. Reconstruction of the laryngeal nerves is an opportunity to quickly return laryngeal function and prevents unwanted secondary functional mechanisms within the vocal organ.

Key words: laryngeal paralysis $\bullet$ voice therapy $\bullet$ voice rehabilitation $\bullet$ laryngeal nerve reconstruction

\section{PRZEBIEG POWROTU FUNKCJI KRTANI U PACJENTA PO REKONSTRUKCJI NERWÓW KRTANIOWYCH WSTECZNYCH}

\section{Streszczenie}

\begin{abstract}
Wprowadzenie: Według danych literaturowych odsetek porażeń krtani po operacjach tarczycy wynosi do kilku procent. Odsetek jest dużo wyższy w przypadku operacji z przyczyn onkologicznych i sięga 20\%. Powrót czynności krtani zależy od stopnia nasilenia uszkodzenia unerwienia. W celu zapewnienia większych szans powrotu funkcji nerwu wymagane jest zastosowanie procedur chirurgicznych. Obecnie stosuje się trzy metody fonochirurgii. Pierwsza opiera się na wprowadzeniu materiałów auto- lub alloplastycznych do fałdu głosowego. Druga ingeruje w szkielet chrzęstny krtani; zgodnie z klasyfikacją Isshiki obejmuje I typ tyreoplastyk, czyli tyreoplastykę medializującą opcjonalnie z uzupełniającym przywiedzeniem nalewki (ang. arytenoid adduction). Trzecia metoda fonochirurgii dotyczy rekonstrukcji nerwów krtaniowych. Coraz częściej stosowane są kombinacje powyżej opisanych metod. Leczenie zachowawcze obejmujące foniatryczną rehabilitację głosu powinno być rozpoczęte jak najwcześniej.
\end{abstract}

Opis przypadku: W pracy przedstawiono opis przypadku pacjenta po operacji tarczycy z powodu raka brodawkowatego, powikłanej obustronnym porażeniem krtani i afonią.

Wnioski: Funkcjonalna Terapia Głosu włączona po wygojeniu rany pooperacyjnej szyi eliminuje nieprawidłowe mechanizmy kompensacyjne procesu fonacji.

Rekonstrukcja nerwów krtaniowych jest szansą na szybki powrót funkcji krtani i zapobiega niepożądanym wtórnym mechanizmom czynnościowym w obrębie narządu głosu.

Słowa kluczowe: porażenie krtani • terapia głosowa $\bullet$ rehabilitacja głosu • rekonstrukcja nerwu krtaniowego

\section{Introduction}

According to the literature, the percentage of laryngeal paralysis after thyroid surgery is as high as several percent. The percentage is much higher for oncological operations and can reach $20 \%[1,2]$. In this latter group of patients, the return of laryngeal function is lower due to infiltration of surrounding tissues and a greater field of surgical procedures, which results in a higher risk of damage to the laryngeal nerves. There are five degrees of nerve damage according to the Sunderland classification [Table 1]. Damage of the first and second degree have a good prognosis; in these cases the return of laryngeal function in the period from 3 to 6 months occurs in $80 \%$ of patients. Prognosis in the higher grades of the classification is generally unsuccessful and surgical procedures 
Table 1. Classification of peripheral nerve injuries according to Sunderland

\begin{tabular}{|c|c|}
\hline Grade & Classification \\
\hline I & $\begin{array}{l}\text { The weakest grade. Transient conduction block due to compression or ischemia, with preserved nerve continuity and focal } \\
\text { demyelination; nerve function returns after } 2-3 \text { weeks; corresponds to neuropraxis in Seddon classification. }\end{array}$ \\
\hline II & $\begin{array}{c}\text { Axon injury, no changes in perineural tissue; nerve regeneration at a rate of } 1 \mathrm{~mm} / \text { day; corresponds to axonotmesis in the } \\
\text { Seddon classification. }\end{array}$ \\
\hline III & Damage of endoneurinum, no change in epi- and perineurinum; the recovery of function depends on intra-bundle fibrosis. \\
\hline IV & Perineurium damage, preserved epineurinum; there is usually a pathological enlargement of the nerve. \\
\hline $\mathrm{V}$ & Anatomical nerve disruption; corresponds to neurotmesis in Seddon classification. \\
\hline
\end{tabular}

are required to increase the likelihood of nerve function recovery. In such cases, microsurgical reconstruction of the nerve provides the best chance for at least partial regeneration of the axons [3]. The reinnervation process is protracted and depends on the individual anatomy of the laryngeal nerves. Complete reinnervation allows the return of laryngeal function. Partial return of innervation is equally important in terms of vocal functionality because it prevents vocal fold atrophy. Current standards presuppose a period of 9-month observation of the reinnervation process prior to a decision about surgical intervention (excluding dyspnea cases) [4].

In order to improve the voice of people with glottal insufficiency resulting from laryngeal paralysis, three surgical methods of phonosurgery are currently used. The first is based on injecting auto or alloplastic materials into the vocal fold $[5,6]$. The second interferes with the skeleton of the laryngeal cartilages; according to the Isshiki classification, it includes type I thyreoplasty, i.e. medialisation thyreoplasty optionally with complementary arytenoid adduction [7]. The third method involves reconstruction of the laryngeal nerves. The procedure is becoming increasingly popular $[8,9]$. The literature reports that the quality of life of patients after reconstruction improves after the procedure, regardless of the time elapsed since the paralysis occurred [10,11]. The most commonly used nerve for transplantation is the ansa cervicalis (the branch innervating the sternohyoid or omohyoid muscle). It is possible to transplant also from sublingual, phrenic, and superior pharyngeal nerves $[3,12,13]$. The preferred surgical technique, ensuring the most effective regeneration process, is "end to end" neurorrhapy [14]. A particular result

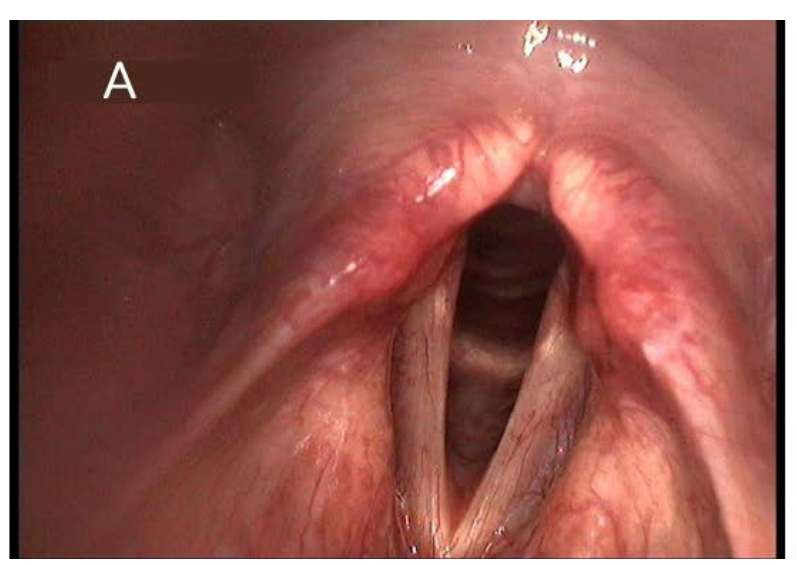

of the reinnervation process of the lower laryngeal nerve is glottal synkinesis. This phenomenon can occur with the 3-5 degree of Sunderland damage and includes incorrect redistribution of innervation of adductor and abductor muscle fibers. As a result, the vocal fold is immobile but retains its tension and phonation position, which ensures the efficiency of the vocal organ [15].

The surgical procedure of laryngeal nerve reconstruction takes about 2.5 hours, which is slightly longer than the procedure of medialisation laryngoplasty [3]. The experience of our centre shows that injection laryngoplasty under general anaesthesia lasts up to 1 hour, whereas with a local anaesthesia it takes 15 minutes [5]. Combinations of the three methods described above are used more and more often. Complementary reconstruction of the laryngeal nerve is preferred, for it improves vocal fold tonus [3]. Conservative treatment, including phoniatric voice rehabilitation, should be started as early as possible. According to the literature, the inclusion of functional voice therapy for up to 6 months from the onset of laryngeal paralysis provides significantly better results [16].

\begin{abstract}
Aim
This paper presents a case report of a patient after thyroid surgery due to papillary carcinoma, complicated by bilateral laryngeal paralysis and aphonia.
\end{abstract}

\section{Case report}

A 27-year-old male, an occupational voice user, was admitted to the Department of Audiology and Phoniatrics of

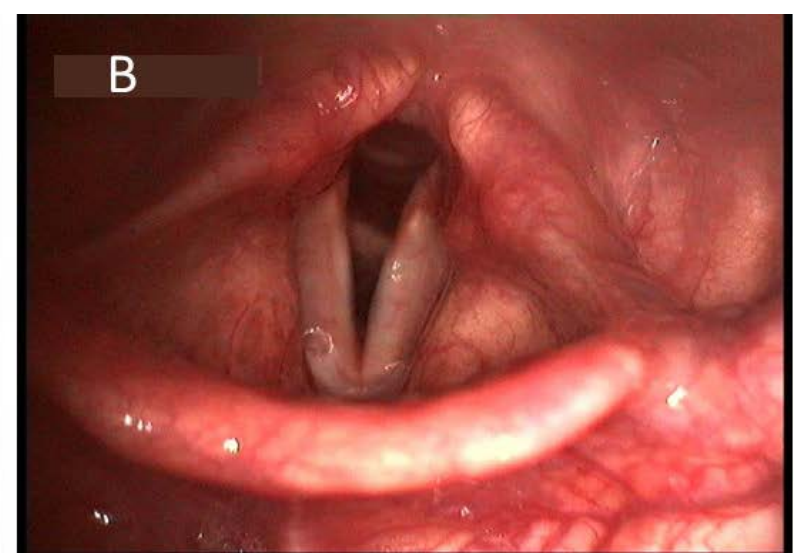

Figure 1. Laryngoscopic image of phonation attempt at admission (A) and after 5 days of functional voice therapy (B). Proximation of the free edges of the vocal folds is visible in B compared to A, especially in the middle part of the glottis 
Table 2. Hoarsness grades based on spectrogram of $a, e, i$ vowels

\begin{tabular}{cc}
\hline Grade & Description \\
\hline 0 & Regular harmonics mixed with noise components in the range of major vowel formants. \\
\hline II & In the second formant of vowels 'e' and 'i', noise components dominate over harmonics. Noise appears also in the high \\
frequency range (over $3000 \mathrm{~Hz}$ ).
\end{tabular}

the Institute of Physiology and Pathology of Hearing in order to perform functional voice therapy due to bilateral paralysis of the larynx. The paralysis occurred after an operation for complete thyroid gland excision, with central lymphadenectomy and radical modified rightsided lymphadenectomy due to papillary carcinoma of the thyroid with metastases to the right and central cervical lymph nodes with infiltration of the laryngeal nerves and trachea. One month after oncological surgery, the patient underwent reconstruction of the laryngeal nerves with use of the right great auricular nerve. Both operations were performed by the oncology surgeon, who also made the decision for reconstruction. Four weeks after the reconstruction the patient was taken under multidisciplinary care aimed at restoring functionality of the vocal organ. At admission to the Department of Audiology and Phoniatrics, a visual, acoustic, and perceptual evaluation of voice quality was performed $[16,17]$. The videostroboscopic examination showed that both folds were paralyzed in an intermediate position and immobile during phonation (Figure 1). Palpation of the neck revealed a too high position of the larynx, excessive tension of the suprahyoid muscles, increased tension of the submental muscles in the resting position, and increased muscle tone of the chest muscles. Multidimentional voice analysis (MDVP) showed abnormalities in the frequency parameters (Jita, Jitt, RAP, PPQ, sPPQ, vF0), amplitude parameters (ShdB, Shim, APQ, sAPQ, vAm), and parameters describing noise and tremor in the voice (NHR, VTI, ATRI, DSH, DUV). Sonographic voice analysis (SPG) revealed stage IV - a severe grade of hoarseness according to the Yanagihara scale (Table 2) [18]. On a perceptual scale, the voice was rated as G3R3B3A3S2. The phonation

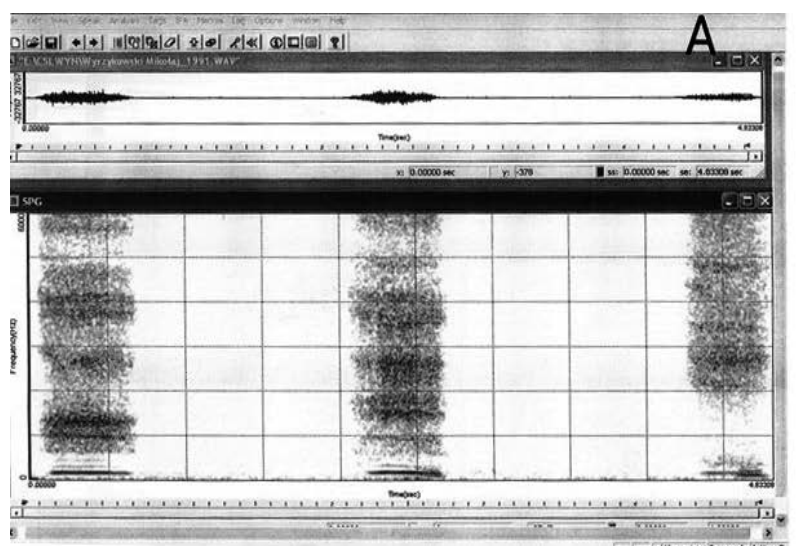

Figure 2. Sonographic analysis of the voice made at admision (A) and discharge (B) from hospital. Visible amplification of the second and third harmonics in B

Journal of Hearing Science $\cdot 2020$ Vol. $10 \cdot$ No. 1 time lasted 3 seconds. The patient scored 61 points in the Voice Handicap Index (VHI) questionnaire, which equates to serious voice disability. During the 5-day hospitalization the patient underwent manual laryngeal therapy, breathing and phonation coordination exercises, vibroaerosol therapy, and Lax Vox exercises. Acoustic voice tests after the treatment did not show any differences in the MDVP analysis. Sonographic analysis of the voice revealed reinforcement of the second and third harmonic components. Energy of the fundamental frequency and harmonic components was stronger compared to that at admission (Figure 2). Moreover, the duration of the phonation time was extended to 5 seconds.

For the next 3 months, manual therapy was continued as an outpatient procedure in a schedule of weekly meetings. Therapy included breathing exercises, elongation of the exhalation phase, passive shortening manoeuvres of the glottis, laryngeal manual therapy involving relaxing and balancing the neck muscles (sternomastoideus, infra and suprahyoid), and reverse phonation. Abnormal compensation mechanisms were eliminated during the therapy. Some 10 weeks after reconstruction surgery, partial mobility of the left vocal fold was observed. Extension of the phonation time to 13 seconds was achieved. MDVP showed abnormal results for the frequency parameters (Jita, Jitt, RAP, PPQ, sPPQ, vF0), amplitude parameters (ShdB, Shim, APQ, sAPQ, vAm), and parameters describing the occurrence of noise and tremor in the voice (NHR, VTI, DSH). SPG showed level III of hoarseness according to the Yanagihara scale. On the perceptual scale, the voice was rated as G2R2B1A1S1. Over the next 4 weeks, there was complete return of the left vocal fold mobility

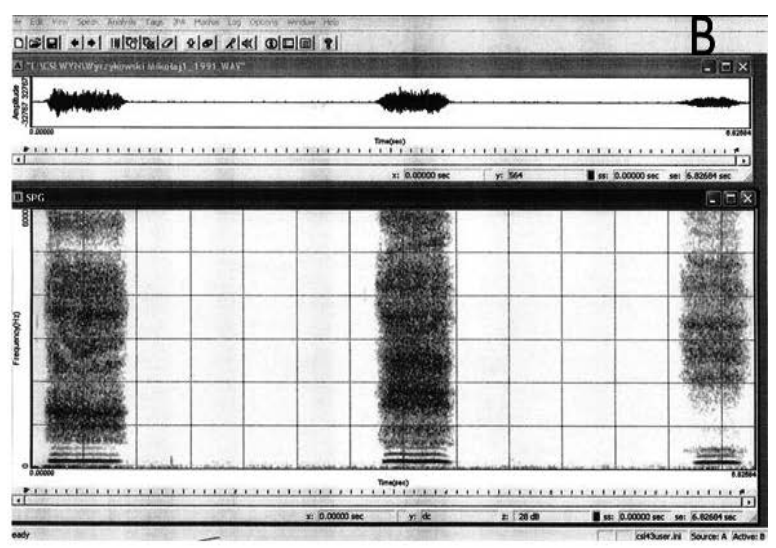



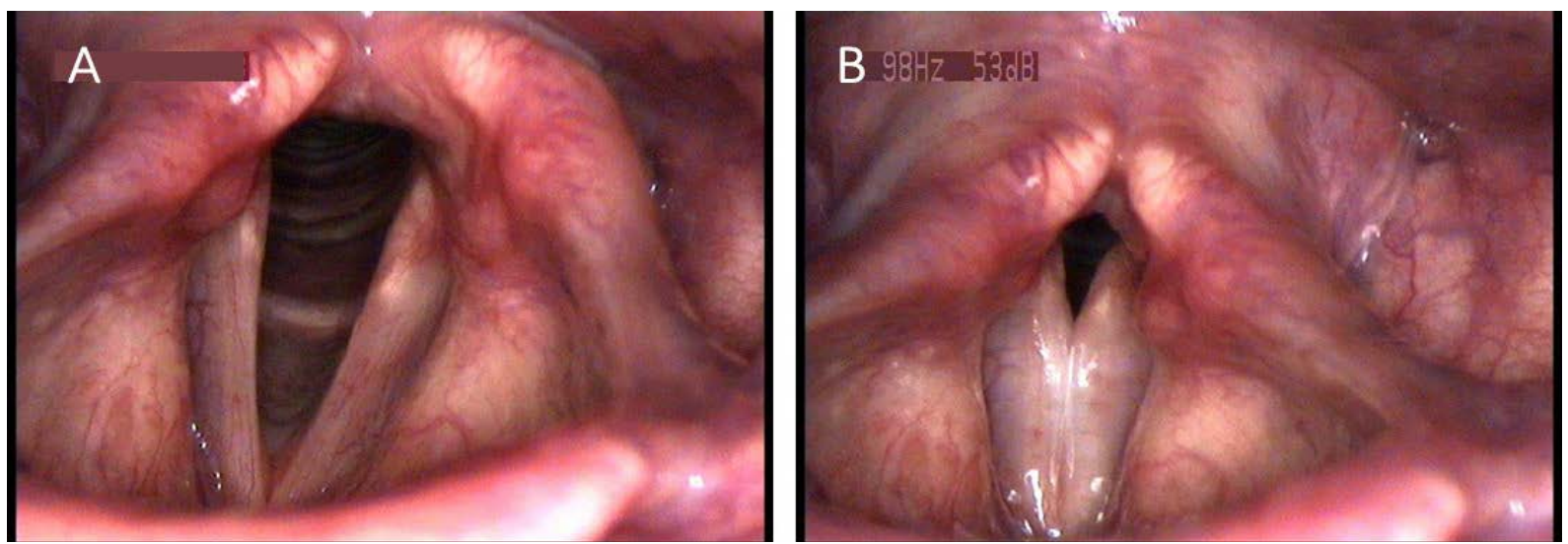

Figure 3. Videostroboscopy during breathing (A) and phonation (B) 4.5 months after reconstruction of the laryngeal nerves. Almost complete return of movement of the left vocal fold is visible, with right vocal fold in the intermediate position. Folds lie at uneven levels
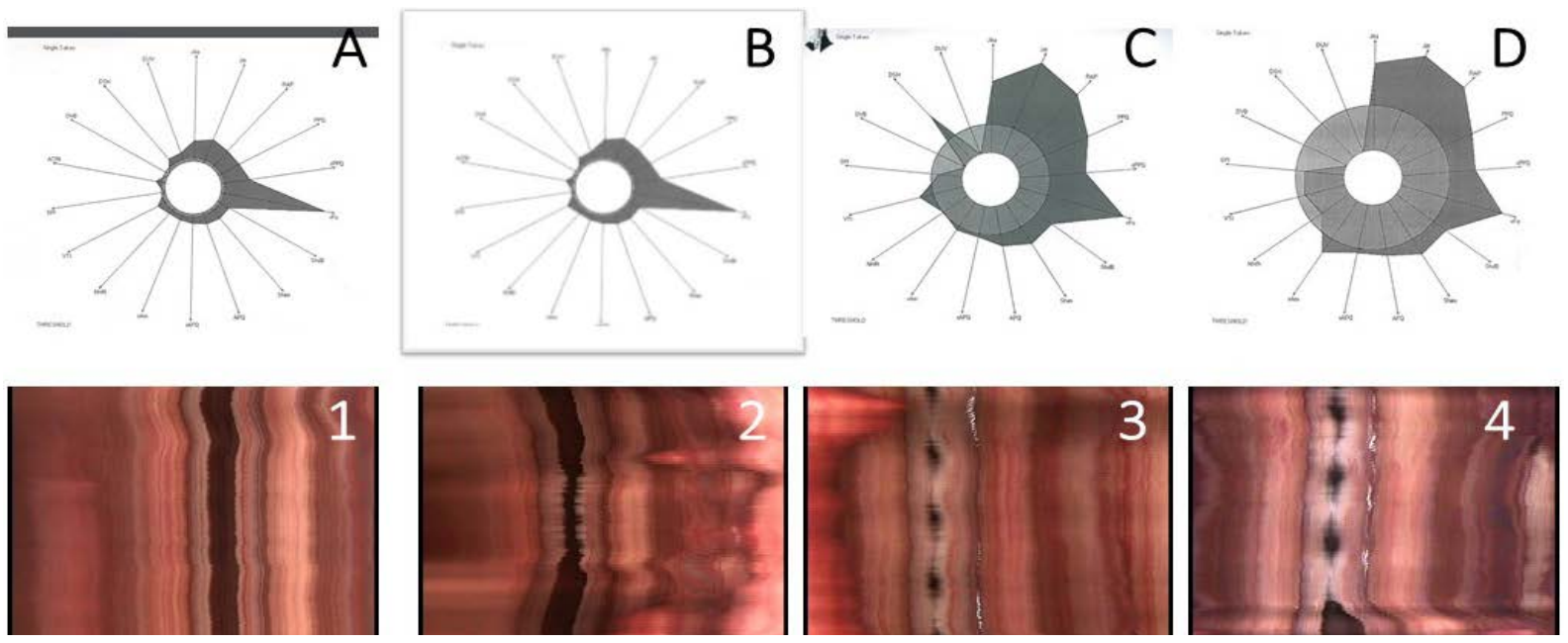

Figure 4. Top line shows MDVP results (A) before treatment, 4 weeks after reconstruction; (B) after 5 days of functional voice therapy; (C) after 10 weeks; (D) 17 weeks after reconstruction. Bottom line presents a videokimographic analysis of the centre of the vocal folds. 1- no mucosal wave on both folds. 2 - irregular vibrations of free edges of vocal folds. 3 - asymmetry of vibrations of vocal folds; vibrations displaced in phase are visible on the right vocal fold, opening phase is extended. 4 - improvement of the amplitude of the vibrations of both vocal folds, smaller displacement of the vocal folds mucosal waves is visible

and tonus of the right vocal fold was observed (Figure 3). The return of an effective voice gave the patient the possibility of returning to work. MDVP showed continued abnormalities within the frequency parameters (Jita, Jitt, RAP, PPQ, sPPQ, vF0) and amplitude parameters (ShdB, Shim, APQ, sAPQ, vAm). SPG showed grade I of hoarseness. The phonation time was 13 seconds. Perceptually, voice was rated as G1R0B0A0S0. In the VHI questionnaire the patient scored 19 points, which meant a slight disability of voice. Figure 4 shows kimographic images, spectrograms, and MDVP illustrating the return of laryngeal phonation efficiency.

\section{Discussion}

In the literature, successful return of vocal fold movement after laryngeal paralysis varies from $26 \%$ to $72 \%[19,20]$. The highest percentage is found in patients with idiopathic paralysis. Authors emphasize the effect of the etiology and neuropathology of the paralysis on the prognosis for return of vocal fold function. Individual laryngeal anatomy may predispose the patient to successfully regain glottal function. The literature shows that in $40 \%$ of human larynges the innervation of the thyroarythenoid muscle comes not only from the inferior but also from the superior laryngeal nerve. In these individuals motoneuron fibers run through the cricothyroid muscle and lamina thyroidea to the thyroarythenoid muscle [21]. Further evidence confirming the high ability of the laryngeal nerves to regenerate is a high percentage of spasmodic dysphonia relapse in patients after section of the recurrent laryngeal nerve [22]. Electromyographic examinations in these patients indicate activation of the laryngeal internal muscles during phonation in iatrogenically paralysed larynges, proving partial neural regeneration $[3,23]$.

The case reported in this work illustrates a successful return of voice organ function after laryngeal nerve reconstruction 
and intensive phoniatric rehabilitation. The effects of reinnervation after reconstructive surgery may be visible after 3-4 months and may take up to a year. The process allows the return of tension and sometimes even mobility of the vocal fold $[24,25]$. Crumley estimated that to maintain the tension of the vocal fold sufficient for phonation, it is necessary to maintain $20 \%$ of the motor fibers [26]. In order to achieve a temporary improvement in the quality of voice until the reinnervation process is completed, injection laryngoplasty is used [3]. Our own experience shows that, depending on the type and place of injection of the hyaluronic acid into the vocal fold, one can get vocal improvement lasting from several months to several years $[5,6]$.

Patients with voice disorder always require individual therapy. The available methods of nerve reconstruction - injection laryngoplasty, medialisation laryngoplasty, and combinations of these methods - allow one to obtain the best results [3]. Currently available surgical and conservative solutions lead to glottal modeling aimed at best functional effect. As the present case demonstrates, early functional voice therapy eliminates abnormal compensatory mechanisms, which can ensure optimal return of laryngeal function after reconstruction of the laryngeal nerves $[16,27]$.
In the presented work, the return of efficient phonation, allowing the patient to return to professional work which required good voice efficiency, was observed 14 weeks after nerve reconstruction. The literature indicates that early reconstruction of the laryngeal nerves gives a better chance of vocal fold movement returning $[28,29]$. This treatment should be considered in patients who have undergone section of the recurrent laryngeal nerve during a surgical procedure, particularly in young people and professional or occupational voice users [30]. The authors agree that, regardless of time from injury, surgery has a good chance of improving tension in the affected fold [31].

\section{Conclusions}

The case report presented in this paper has described therapeutic - surgical and conservative - options used in a patient with laryngeal paralysis. The use of a rarely applied laryngeal nerve reconstruction procedure has been described. Reconstruction of the laryngeal nerves offers a chance for a quick return of laryngeal function and prevents unwanted secondary functional mechanisms within the vocal organ. The paper has shown that Functional Voice Therapy, started just after healing of the postoperative wound of the neck, eliminates abnormal compensatory mechanisms in phonation.

\section{References}

1. Calo PG, Pisano G, Medas F. Risk factors in reoperative thyroid surgery for recurrent goitre: our experience. G Chir, 2012;33:335-338.

2. Hayward NJ, Grodski S, Yeung M. Recurrent laryngeal nerve injury in thyroid surgery: a review. ANZ J Surg, 2013;83(1-2):15-21.

3. Blitzer A, Brin M, Ramig L. Neurologic Disorders of the Larynx. Thieme 2011; 117-147.

4. Schneider W, Wolf S, Krause J. Electromyographische Untersuchung und Verlaufsbeobachtung von beidseitigen Rekurrensparesen nach Schilddrusenoperationen. HNO, 1997;45:551-555.

5. Szkiełkowska A, Miaśkiewicz B, Remacle M, Krasnodębska P, Skarżyński H. Quality of the voice after injection of hyaluronic acid into the vocal fold. Med Sci Mon, 2013;19:276.

6. Miaśkiewicz B, Szkiełkowska A, Piłka A, Skarżyński H. Assessment of acoustic characteristics of voice in patients after injection laryngoplasty with hyaluronan. Polish Otolaryngol, 2016;70(1):15-23.

7. Isshiki $\mathrm{N}$, Tanabe $\mathrm{M}$, Sawada $\mathrm{M}$. Arytenoid adduction for unilateral vocal cord paralysis. Arch Otolaryngol, 1978;104:555-558.

8. Dzodic R, Markovic I, Santrac N, Buta M, Djurisic I, Lukic S. Recurrent laryngeal nerve liberations and reconstructions: a single institution experience. World J Surg, 2016;40(3):644-651.

9. Miyauchi A, Inoue H, Tomoda C, et al. Improvement in phonation after reconstruction of the recurrent laryngeal nerve in patients with thyroid cancer invading the nerve. Surgery, 2009; 146(6):1056-1062.

10. Chen SC, Zheng HL, Zhou SM, et al. Nerve exploration and decompression for traumatic recurrent laryngeal nerve injuries induced by thyroid gland surgery. Zhonghua Er Bi Yan Hou Ke Za Zhi, 2004;39(8):464-468.

11. Lyu Z, Xu W, Zou J, et al. Recurrent laryngeal nerve decompression for bilateral recurrent laryngeal nerve paralyses after thyroid surgery. Zhonghua Er Bi Yan Hou Tou Jing Wai Ke Za Zhi, 2014;49(11):885-888.
12. Fancello V, Nouraei S, Heathcote K. Role of reinnervation in the management of recurrent laryngeal nerve injury: current state and advances. Curr Opin Otolaryngol Head Neck Surg, 2017; 25(6), 480-485.

13. Li M, Chen S, Wang W, Chen D, Zhu M, Liu F, Zheng H. Effect of duration of denervation on outcomes of ansa-recurrent laryngeal nerve reinnervation. Laryngoscope, 2014;124(8):1900-1905.

14. Zheng H, Zhou S, Chen S, Li Z, Cuan Y. An experimental comparison of different kinds of laryngeal muscle reinnervation. Otolaryngol Head Neck Surg, 1998;119:540-547.

15. Pei Y, Chang W, Chuang H, Chang C, Fang T. Implications of synkinesis in unilateral vocal fold paralysis. Otolaryngol Head Neck Surg, 2017;157(6):1017-1024.

16. Krasnodebska P, Domeracka-Kołodziej A, Szkiełkowska A, Mularzuk M, Sokołowska-Łazar D, Wilhelmsen K, Panasiewicz A. Assessment of short-term comprehensive voice therapy in patients with unilateral paralysis of the larynx. Otolaryngol Pol 2018;72(2):35-43.

17. Krasnodębska P, Szkiełkowska A. Two videostrobokymographic software packages for evaluating Open Quotient of the vocal folds: user report. J Hear Sci, 2017; 7(4):28-32.

18. Maniecka-Aleksandrowicz B, Domeracka-Kołodziej A. Dysphonia and hoarseness. Magazyn Otolaryngologiczny 2004;3(1):17-25.

19. Yamada M, Hirano M, Ohkubo H. Recurrent laryngeal nerve paralysis. A 10-year review of 564 patients. Auris Nasus Larynx, 1983;10:1-15.

20. Daya H, Hosni A, Bejar-Solar I, Evans J, Bailey C. Pediatric vocal fold paralysis: a long term retrospective study. Arch Otolaryngol Head Neck Surg, 2000;126:21-25.

21. Sanders I, Wu B, Mu L, Li Y, Biller H. The innervation of the human larynx. Arch Otolaryngol Head Neck Surg, 1993;119(9):934-939.

22. Aronson A, De Santo L. Adductor spastic dysphonia: three years after recurrent laryngeal nerve section. Laryngoscope, 1983;93:1-8. 
23. Sulica L, Brin M, Blitzer A, Stewart C. Botulinum toxin management of adductor spasmodic dysphonia after failed recurrent laryngeal nerve section. Ann Otol Rhinol Laryngol, 2003;112(6), 499-505.

24. Olson D, Goding G, Michael D, Acoustic and perceptual evaluation of laryngeal reinnervation by ansa cervicalis transfer. Laryngoscope 1998;108:1767-1772.

25. Maronian N, Waugh P, Robinson L, Hillel A. Electromyographic findings in recurrent laryngeal nerve reinnervation. Ann Otol Rhinol Laryngol, 2003;112:314-323.

26. Crumley R. Experiments in laryngeal reinnervation. Laryngoscope, 1982;92:1-27.

27. D'Alatri L. Role of early voice therapy in patients affected by unilateral vocal fold paralysis. J Laryngol Otol, 2008;122(9):936-941.
28. Miyauchi, A. Improvement in phonation after reconstruction of the recurrent laryngeal nerve in patients with thyroid cancer invading the nerve. Surgery, 2009;146(6):1056-1062.

29. Wei W. Contralateral ansa cervicalis-to-recurrent laryngeal nerve anastomosis for unilateral vocal fold paralysis: a long-term outcome analysis of 56 cases. Laryngoscope, 2011;121(5):1027-1034.

30. Marina M, Marie J, Birchall M. Laryngeal reinnervation for bilateral vocal fold paralysis. Curr Opin Otolaryngol Head Neck Surg, 2011;19(6):434-438.

31. Tanaka S, Minoru H, Keichi C. Some aspects of vocal fold bowing. Ann Otol Rhinol Laryngol 1994;103(5):357-362. 